\title{
Penerapan Single Page Application Pada Proses Pengisian Online Data Rencana Studi Mahasiswa
}

\author{
Aryani Ristyabudi ${ }^{1 *}$, Husni Thamrin ${ }^{1}$ \\ ${ }^{1}$ Program Studi Informatika \\ Universitas Muhammadiyah Surakarta \\ *aryani.ristya@gmail.com, husni.thamrin@ums.ac.id
}

\begin{abstract}
ABSTRAK
Universitas Muhammadiyah Surakarta (UMS) telah membangun aplikasi berbasis web untuk pengisian data rencana studi mahasiswa dan menerapkannya selama belasan tahun. Paper ini mendeskripsikan sebuah studi untuk mempertimbangkan penerapan konsep Single Page Application (SPA) ke dalam aplikasi tersebut. SPA adalah merupakan teknik baru yang menggunakan satu halaman web saja untuk beberapa tahap dalam satu kesatuan aktivitas. Penerapan SPA dalam proses pengisian data rencana studi dilakukan menggunakan teknologi web termutakhir yaitu HTML5 dan AngularJS. Kinerja aplikasi yang baru diukur dengan mencermati jumlah data yang ditransfer dan waktu yang dibutuhkan untuk melakukan pengisian data rencana studi seorang mahasiswa. Penggukuran dilakukan menggunakan Wireshark. Hasil pengujian membuktikan bahwa pengisian data rencana studi menggunakan aplikasi dengan SPA membutuhkan transfer data kurang dari sepersepuluh dari proses menggunakan aplikasi tanpa SPA. Aplikasi dengan SPA menghemat total waktu yang dibutuhkan selama proses pengisian data menjadi sepertiga dari waktu yang diperlukan jika proses dilakukan menggunakan aplikasi tanpa SPA.
\end{abstract}

Kata kunci: single page application, JavaScript, AngularJS, rencana studi

\section{Pendahuluan}

Setiap awal semester, seorang mahasiswa membuat rencana studi yang harus disetujui oleh pembimbing akademik [1]. Pada masa lalu, sebelum komputerisasi merambah proses perekaman data rencana studi, rencana studi mahasiswa ditulis pada selembar kertas yang disebut Kartu Rencana Studi atau lebih dikenal dengan KRS. Ketika proses pengisian KRS berubah menggunakan komputer, istilah KRS masih sering digunakan meskipun proses tersebut sama sekali tidak menggunakan kertas berbentuk kartu. Untuk membedakan dengan proses pengisian kartu rencana studi yang menggunakan kertas, pengisian data rencana studi menggunakan komputer sering diistilahkan sebagai KRS online. Universitas Muhammadiyah Surakarta (UMS) telah menerapkan sistem KRS online selama belasan tahun. Buku Panduan Akademik menyebutkan bahwa pengambilan KRS mahasiswa dilaksanakan langsung melalui prosedur KRS online melalui komputer. Sistem KRS online UMS merupakan salah satu dari bagian aplikasi terpadu UMS yang dirancang untuk memfasilitasi aktivitas penyusunan atau pengaksesan sistem administrasi dan informasi akademik [2].

Pada sistem yang sedang berjalan sekarang, proses pengisian data rencana studi memerlukan akses ke beberapa halaman web, yaitu halaman login, halaman penyuntingan profil, halaman daftar mata kuliah, halaman penambahan data rencana studi, dan lain-lain. Beberapa halaman ditampilkan secara berulang. Setiap halaman web dibuat atau dikonstruksi oleh browser setelah selesai mengambil (loading) seluruh data dan metadata dari server terkait halaman yang akan ditampilkan. Metadata yang dimaksud termasuk tag HTML (bypertext markup language) dan kode CSS (content style sheet). Menampilkan beberapa halaman web berarti mengambil data dan metadata dari server. Data yang berasal dari basis data selalu diambil ulang dari server basis data untuk memastikan kemutakhiran informasi yang ditampilkan. Oleh karena itu, menampilkan beberapa halaman secara berulang memerlukan banyak proses transfer data dan waktu.

Belakangan ini telah dikembangkan teknik antar muka yang disebut Single Page Application (SPA). Istilah SPA merujuk pada aplikasi berbasis web yang hanya menampilkan satu halaman saja. Artinya, meskipun pengguna beralih ke menu lain, URL tidak menunjukkan perubahan. Semua komponen utama pada SPA, seperti CSS, skrip dan sumber daya lain yang diperlukan diambil pada satu waktu di halaman utama. Komponen atau konten yang sesuai diambil secara dinamis tergantung pada kebutuhan interaksi atau permintaan pengguna [3]. Server hanya perlu mengirim dan menyegarkan bagian tertentu sesuai permintaan pengguna sehingga diharapkan dapat menghemat bandwidth. Browser dapat mengubah tampilan pada bagian tertentu saja secara dinamis. Karena bandwidth yang digunakan dalam SPA tergolong kecil, SPA dapat memberikan responsivitas yang tinggi dan kenyamanan bagi pengguna, tidak membingungkan dan menjengkelkan bagi pengguna [4]. 
Tulisan ini menguraikan upaya membuat Single Page Application untuk proses perekaman data rencana studi mahasiswa UMS dan menguji aplikasi tersebut dibandingkan dengan sistem KRS online di Universitas Muhammadiyah Surakarta. Objek penelitian adalah sistem KRS online UMS yang diakses oleh mahasiswa aktif UMS. Hasil penelitian menunjukkan bahwa aplikasi SPA dapat membantu mengurangi masalah yang muncul terkait lamanya proses KRS online dengan melakukan penghematan bandwidth dan waktu akses terhadap sistem.

\section{Metode}

Metode penelitian yang digunakan adalah eksperimen dan observasi, yaitu dengan membuat Single Page Application untuk merekam data rencana studi mahasiswa dan membandingkan kinerja aplikasi SPA dibanding aplikasi KRS online yang sedang berjalan. Kinerja aplikasi diukur dari jumlah data yang ditransfer antara server dan browser pada proses perekaman pengambilan satu mata kuliah di KRS. Selain itu, kinerja aplikasi diukur dari prediksi waktu yang dibutuhkan untuk menyelesaikan proses pengambilan mata kuliah.

\section{1) Waktu dan Tempat}

Waktu yang dibutuhkan untuk menyelesaikan penelitian ini kurang lebih lima bulan terhitung dari bulan November 2015 sampai dengan Maret 2016, dan bertempat di Universitas Muhammadiyah Surakarta.

\section{2) Alat dan Bahan}

Peralatan yang digunakan selama penelitian terdiri dari software dan hardware. Software yang digunakan antara lain Sublime Text 2, XAMPP, Google Chrome, Visual Paradigm Community Edition, DBDesigner 4, dan Wireshark. Sedangkan hardware yang digunakan adalah laptop dengan spesifikasi prosesor Intel Core i3, RAM 2 GB, harddisk 500 GB dan sistem operasi Windows 7 serta smartphone dengan spesifikasi prosesor 8 Core 1,5 GHz, RAM 2 GB, ROM 8 GB dan memori eksternal 4 GB.

Bahan yang digunakan untuk penelitian ini adalah data mahasiswa aktif, data mata kuliah dan data pengambilan studi (Kartu Rencana Studi, KRS) mahasiswa aktif Fakultas Komunikasi dan Informatika Universitas Muhammadiyah Surakarta semester gasal tahun 2015.

\section{3) Perancangan SPA}

Perancangan Single Page Application untuk merekam proses pengambilan mata kuliah meliputi desain atau rancangan sistem dengan menggunakan model Unified Modelling Language (UML). Diagram yang digunakan antara lain: use case diagram, class diagram, sequence diagram, dan activity diagram. Berikut model UML dari aplikasi SPA yang dibuat untuk penelitian ini.

\section{a. Use Case Diagram}

Use case diagram menggambarkan fungsionalitas yang diharapkan dari suatu sistem. Use case diagram merepresentasikan sebuah interaksi antara aktor dengan sistem, seperti yang digambarkan dalam Gambar 1 terkait interaksi antara mahasiswa dengan sistem. Aktor utama dalam aplikasi SPA ini adalah mahasiswa. Mahasiswa dapat melakukan empat aktivitas meliputi login ke dalam sistem, mengubah password, menambah mata kuliah dan menghapus mata kuliah.

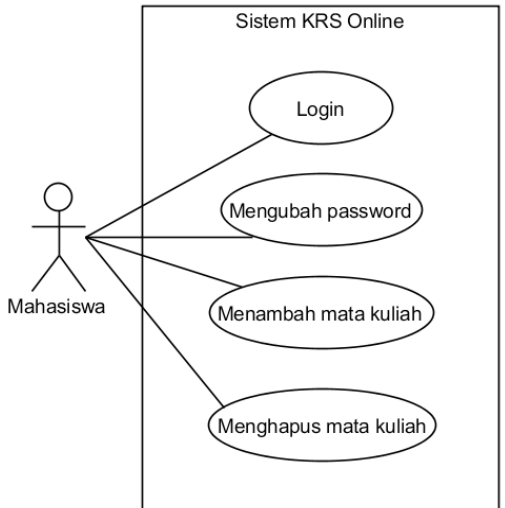

Gambar 1. Use Case Diagram Mahasiswa

\section{b. Class Diagram}

Class diagram adalah sebuah diagram yang menggambarkan kelas/objek beserta atribut atau properti objek yang ada dalam sistem. Diagram ini dapat digunakan untuk mendeskripsikan aktivitas yang dilakukan objek atau layanan yang tersedia untuk mengubah nilai atribut objek. Aktivitas dalam kelas atau objek diwujudkan dalam bentuk fungsi, prosedur atau method. Aplikasi SPA yang dibuat dalam penelitian ini menggunakan class diagram seperti ditunjukkan pada Gambar 2. Diagram yang dimaksud menggambarkan bagaimana kelas/objek direkam dalam basis data (diwujudkan dalam tabel) dan keterkaitan antar objek (diwujudkan dalam bentuk relationship). Terdapat dua kelas utama dalam aplikasi yaitu kelas Mahasiswa dan kelas Mata_Kuliah. Kedua kelas mempunyai hubungan yaitu "Mahasiswa mengambil Mata_Kuliah" dan hubungan itu diwujudkan dalam bentuk tabel bernama "KRS".

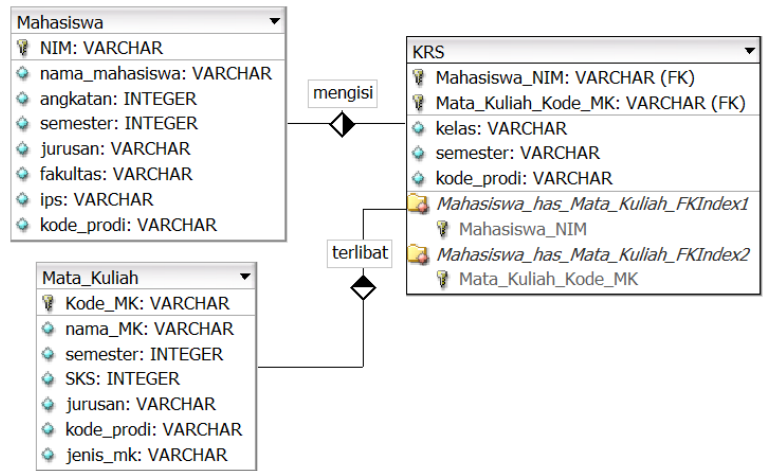

Gambar 2. Class Diagram Sistem KRS

\section{c. Sequence Diagram}

Sequence diagram adalah suatu diagram yang menggambarkan alur komunikasi antar obyek dengan waktu penyampaian pesan yang digambarkan secara vertikal. Terdapat empat sequence diagram dalam perancangan sistem KRS online, yaitu proses login, proses pengubahan password, proses penambahan mata kuliah dan proses penghapusan mata kuliah dari daftar KRS.

Sequence diagram untuk proses login diterapkan saat mahasiswa melakukan login seperti pada Gambar 3. Proses diawali dengan mengisikan data login seperti 
username dan password pada form login, kemudian sistem akan melakukan validasi data ketika mahasiswa mengklik tombol "Login". Validasi oleh sistem dilakukan dengan cara mencocokkan data yang dimasukkan oleh mahasiswa dengan data yang ada pada basis data. Apabila data tidak cocok, maka akan ditampilkan peringatan bahwa data yang dimasukkan salah. Apabila data sesuai, sistem akan menampilkan halaman utama.

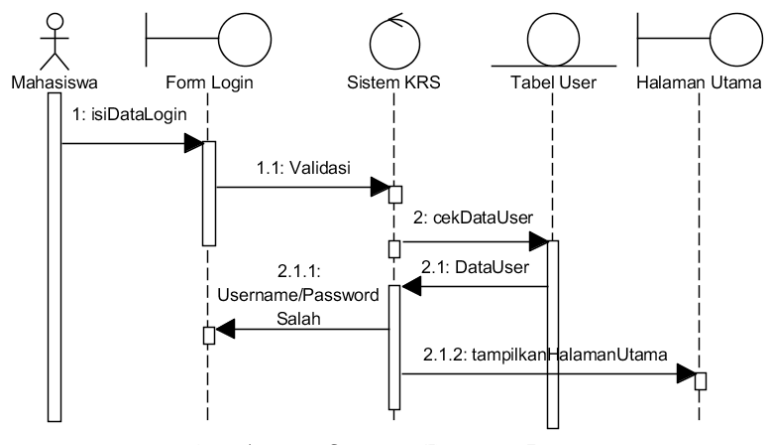

Gambar 3. Sequence Diagram Login

Sequence diagram mengubah password menampilkan proses ketika mahasiswa mengubah password yang digunakan sebagai data login seperti pada Gambar 4. Mahasiswa mengisikan data password baru dan dikonfirmasi dengan data password lama. Melalui proses request, data user, password lama dan password baru dikirim ke sistem (server), server kemudian akan menguji kecocokan data password lama yang dimasukkan oleh mahasiswa dengan data yang ada pada basis data. Jika sesuai, maka sistem akan memutakhirkan password dengan menyimpan password baru ke basis data.

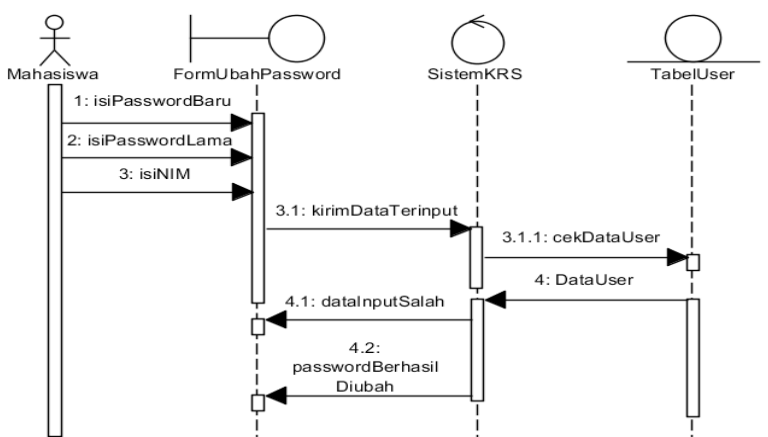

Gambar 4. Sequence Diagram Ubah Password

Sequence diagram menambah mata kuliah menampilkan proses ketika mahasiswa menambah data mata kuliah yang diambil ke dalam KRS, atau menambah matakuliah ke dalam daftar rencana studinya (Gambar 5). Proses dimulai dengan memilih mata kuliah dari sebuah daftar mata kuliah yang ditawarkan. Selanjutnya setelah mengklik tombol kirim, data mata kuliah baru akan dikirim ke sistem (server). Selanjutnya sistem akan mengecek daftar matakuliah yang telah dipilih mahasiswa dan melihat apakah penambahan data diperkenankan (yaitu terkait jumlah kredit maksimal yang boleh diambil mahasiswa). Jika kondisi memungkinkan, server akan menambah data mata kuliah pada daftar rencana studinya di dalam basis data.

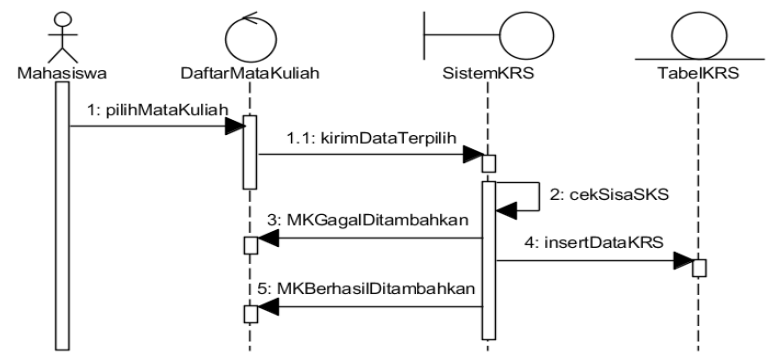

Gambar 5. Sequence Diagram Tambah Mata Kuliah

Sequence diagram menghapus mata kuliah menampilkan proses ketika mahasiswa menghapus mata kuliah yang sebelumnya telah dipilih (ada dalam KRS), seperti yang ditampilkan pada Gambar 6 . Mahasiswa memilih mata kuliah yang ada dalam daftar mata kuliah yang telah direncanakan. Kemudian sistem akan menghapus data mata kuliah yang telah dipilih sebelumnya dari tabel KRS pada basis data.

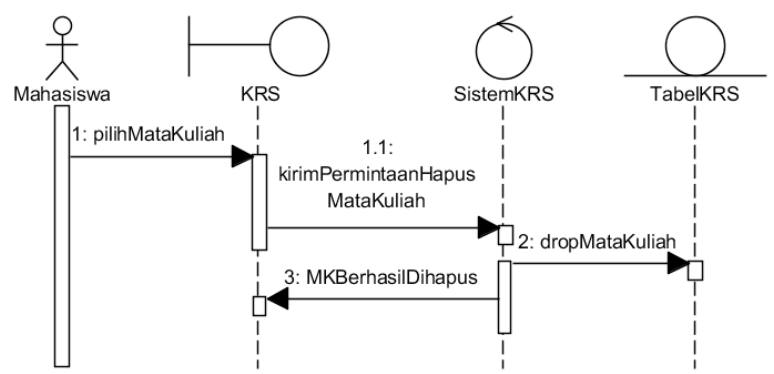

Gambar 6. Sequence Diagram Hapus Mata Kuliah

\section{Hasil dan Diskusi}

\subsection{Hasil Penelitian}

Rancangan Single Page Application (SPA) yang dibuat dalam penelitian ini sebelum diujikan di-deploy pada pada sebuah server web berikut dengan basis data yang diperlukan dalam pengujian. Sesuai dengan tahapan perancangan, tampilan dari aplikasi terbagi menjadi lima halaman tampilan yaitu, tampilan login, tampilan halaman utama, tampilan daftar rencana studi (atau halaman KRS), tampilan tambah mata kuliah, dan tampilan ubah password.

Tampilan login merupakan tampilan yang muncul pertama kali ketika membuka aplikasi SPA. Tampilan login ini digunakan untuk memvalidasi pengguna yang diizinkan dan yang tidak diizinkan mengakses halaman utama. Dalam tampilan ini, terdapat form yang terdiri dari dua field untuk input data yaitu username dan password, serta sebuah tombol untuk mengirim data dalam dua field tadi ke dalam sistem (server).

Tampilan utama merupakan halaman yang pertama kali ditampilkan setelah mahasiswa melakukan login dan diizinkan masuk ke dalam sistem (Gambar 7). Tampilan ini terdiri dari header, konten dan footer. Bagian header berisi judul aplikasi yang disertai dengan logo dan nama universitas. Judul aplikasi SPA tetap menggunakan nama "Sistem KRS Online" yang merupakan nama yang telah dikenal luas. Bagian konten terdiri atas tiga bagian, yaitu 
bagian sebelah kiri, kanan atas, dan kanan bawah. Bagian konten sebelah kiri mengandung menu sistem, yaitu menu "KRS", “TAMBAH MATA KULIAH", "UBAH
PASSWORD", dan "LOGOUT". Bagian konten sebelah kanan mengandung kotak informasi berisi deskripsi singkat mengenai sistem KRS online UMS.

\section{Sistem KRS Online @ Universitas Muhammadiyah Surakarta}

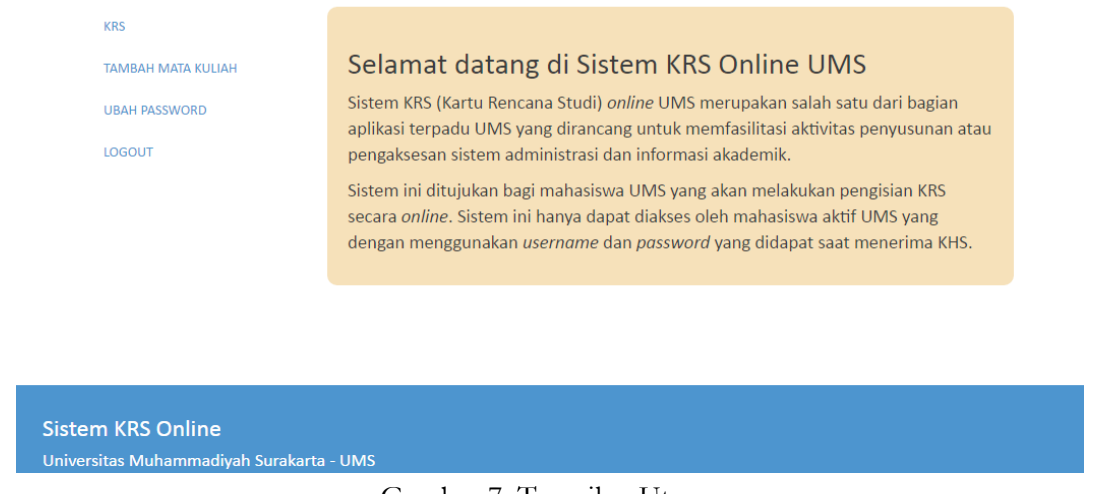

Gambar 7. Tampilan Utama

Tampilan daftar rencana studi atau KRS merupakan halaman yang ditampilkan ketika mahasiswa mengklik menu "KRS" (lihat Gambar 8). Di bagian konten sebelah kanan atas terdapat informasi singkat mengenai data diri mahasiswa yang bersangkutan. Di bagian konten sebelah kanan bawah berisi daftar mata kuliah yang telah direncanakan (tabel KRS) oleh mahasiswa yang bersangkutan. Konten sebelah kanan akan berubah-ubah sesuai aksi yang dilakukan oleh mahasiswa. Tabel KRS yang ditampilkan memuat informasi mengenai kode mata kuliah, nama mata kuliah, semester mata kuliah yang bersangkutan, jumlah SKS, kelas, dan sebuah pilihan untuk menghapus mata kuliah yang bersangkutan

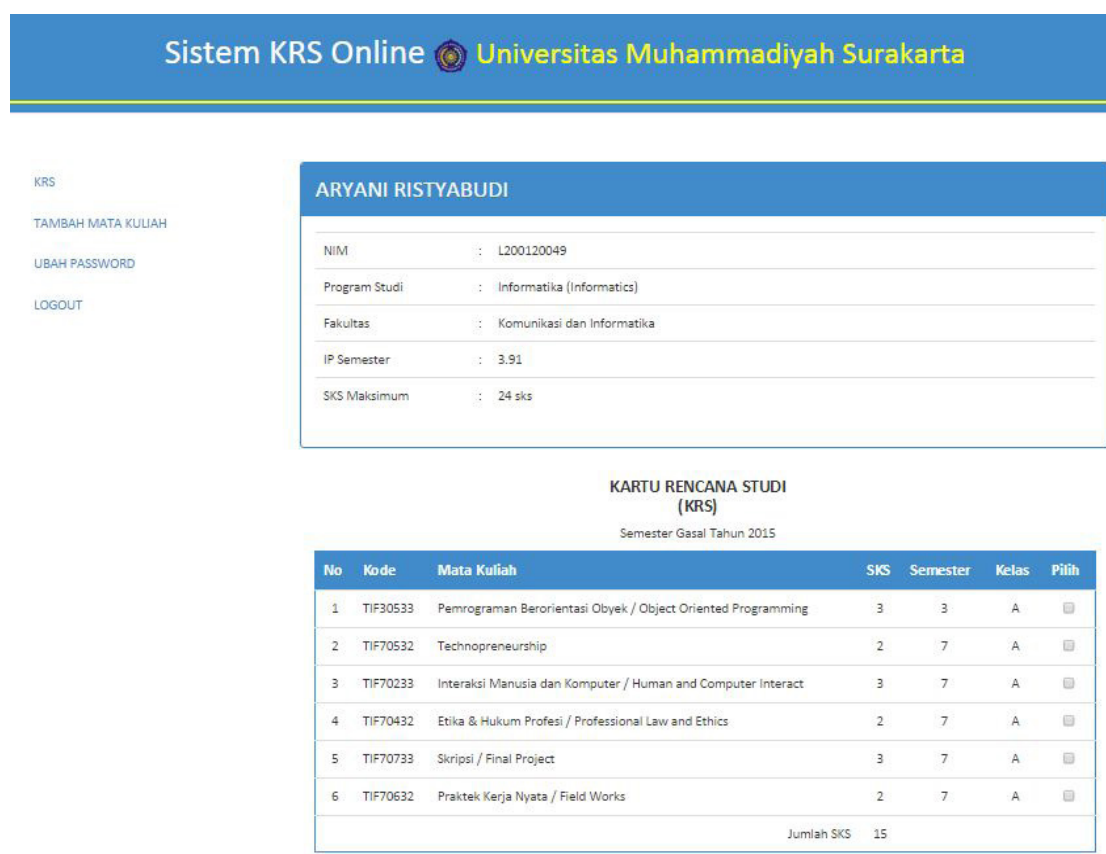

Gambar 8. Tampilan KRS

Tampilan tambah mata kuliah merupakan tampilan ketika mahasiswa mengklik menu "TAMBAH MATA KULIAH” (Gambar 9). Tampilan ini mirip dengan tampilan utama. Perbedaananya ada pada bagian konten sebelah kanan bawah yang menampilkan daftar mata kuliah yang bisa ditambahkan oleh mahasiswa pada semester aktif. Tabel ini berisi beberapa informasi seperti kode mata kuliah, nama mata kuliah, semester mata kuliah yang bersangkutan, jumlah SKS, pilihan kelas, dan pilihan untuk menambahkan dengan mengklik tombol "Tambahkan". 


\section{Sistem KRS Online (2) Universitas Muhammadiyah Surakarta}

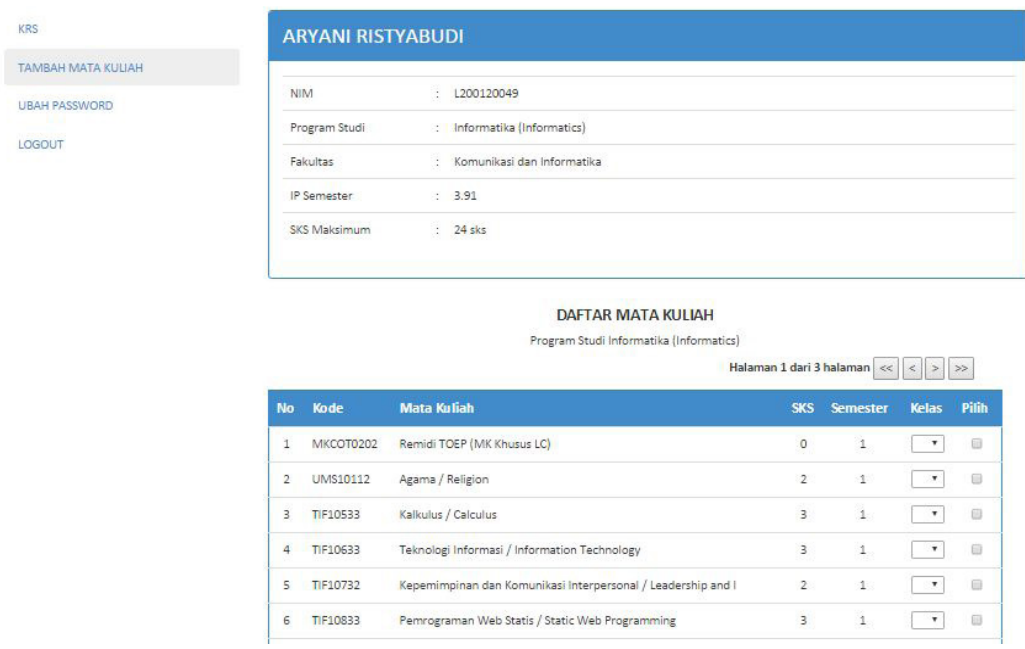

Gambar 9. Tampilan Tambah Mata Kuliah

\section{Sistem KRS Online (Q) Universitas Muhammadiyah Surakarta}
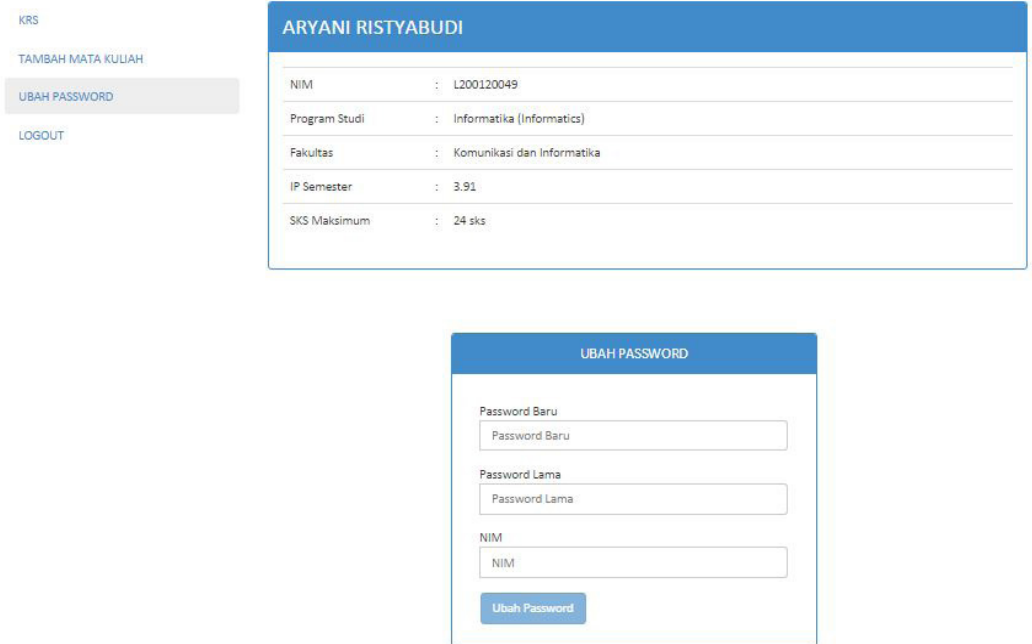

Gambar 10. Tampilan Ubah Password

Tampilan ubah password ditampilkan setelah mahasiswa mengklik menu "UBAH PASSWORD". Tampilan ini mirip dengan tampilan utama (lihat Gambar 10). Yang membedakan adalah pada bagian konten sebelah kanan bawah, yaitu menampilkan sebuah form untuk mengubah password. Dalam form ini, terdapat tiga field untuk input data password baru, password lama dan NIM mahasiswa yang bersangkutan, serta sebuah tombol untuk eksekusi data yang diinputkan oleh mahasiswa untuk kemudian diproses apakah passsword berhasil untuk diubah atau tidak.

\subsection{Pengujian dengan Wireshark}

Untuk menunjukkan perbaikan kinerja aplikasi SPA yang telah dibuat, aplikasi dibandingkan dengan sistem KRS online yang masih berjalan. Pengujian menggunakan dua metrik yaitu total waktu dan ukuran data yang ditransfer (dalam byte). Kedua metrik tersebut diukur menggunakan software Wireshark. Wireshark digunakan karena merupakan aplikasi penganalisa jaringan, yang mampu menangkap (capturing) setiap data yang lewat melalui salah satu antar muka jaringan dan menampilkannya dengan rinci [5]. Wireshark dapat menangkap data waktu (dalam detik) dan jumlah data transfer (dalam byte) yang lewat ketika melakukan proses KRS. Tujuannya adalah untuk membandingkan data transfer antara sistem KRS online dan aplikasi SPA sehingga dapat mengetahui sistem mana yang mempunyai data transfer lebih kecil serta sistem mana yang lebih cepat (hemat waktu).

\section{1) Pengujian pada sistem KRS online}

Pengujian dengan Wireshark dilakukan dengan pertama kali mencari alamat IP dari sistem KRS online yaitu dengan alamat web "akademik.ums.ac.id" yang didapatkan dengan menggunakan perintah "ping akademik.ums.ac.id" pada Command Prompt. Dari hasil 
ping, didapatkan alamat IP sistem adalah 103.226.174.195. Alamat IP tersebut kemudian digunakan sebagai filter pada Wireshark dengan menggunakan perintah filter ip.src $==103.226 .174 .195 \quad||$ ip.dst $==103.226 .174 .195$ (lihat Gambar 11). Filter ini bertujuan untuk menyaring data yang ditampilkan Wireshark yaitu hanya yang bersumber dari dan menuju ke alamat IP yang difilter.

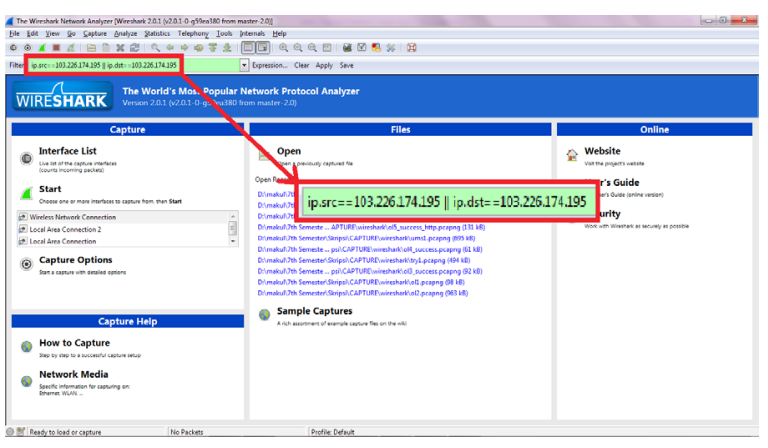

Gambar 11. Analisa dengan Filter ip.src $==103.226 .174 .195$ || ip.dst $==103.226 .174 .195$
Setelah memberi filter, langkah selanjutnya adalah menginisiasi proses capturing pada Wireshark. Ketika proses tersebut berjalan, barulah dilakukan aktivitasaktivitas yang ada dalam aplikasi atau dalam sistem KRS online. Pada penelitian ini, proses capturing dilakukan selama terjadi aktivitas login, mengisi rencana studi, membatalkan data rencana studi, mengganti password, dan logout. Detil tahapan aktivitas yang dilakukan saat pengujian sistem KRS online diperlihatkan pada Gambar 12. Setelah seluruh tahapan aktivitas dikerjakan, proses capturing pada Wireshark diakhiri dan hasilnya disimpan pada sebuah berkas berekstensi pcap (*.pcap).

Aktivitas-aktivitas dibawah ini yang dianalisis menggunakan Wireshark. Wireshark akan menangkap semua data yang lewat ketika sistem diakses, tiap data tersebut memiliki informasi seperti waktu, alamat IP asal, alamat IP tujuan, protokol yang digunakan, panjang data (dalam byte) serta informasi lebih lanjut mengenai data tersebut. Informasi ini terlihat seperti pada Gambar 13. Setelah aktivitas yang dilakukan saat mengakses sistem telah selesai, maka selanjutnya menghentikan proses capturing pada Wireshark.

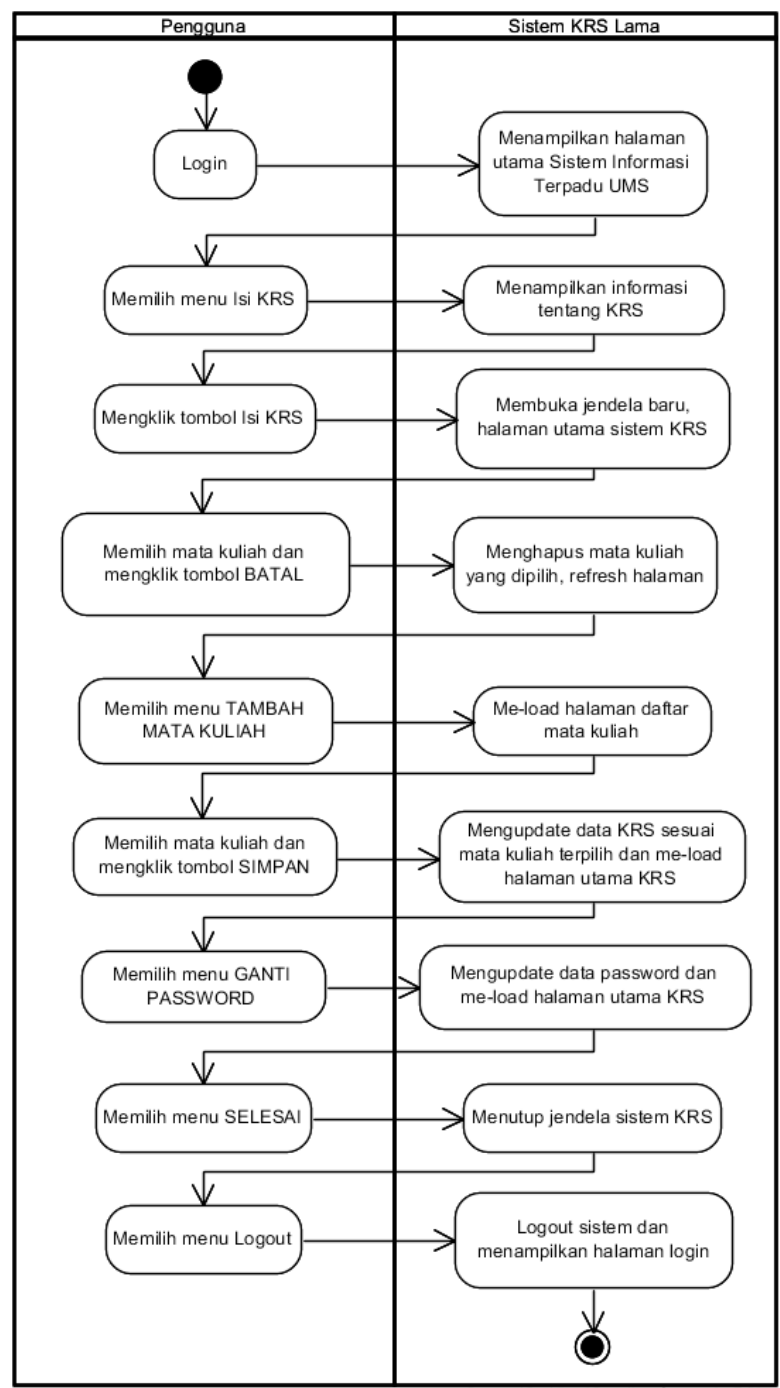

Gambar 12. Aktivitas Selama Mengakses Sistem KRS Online 


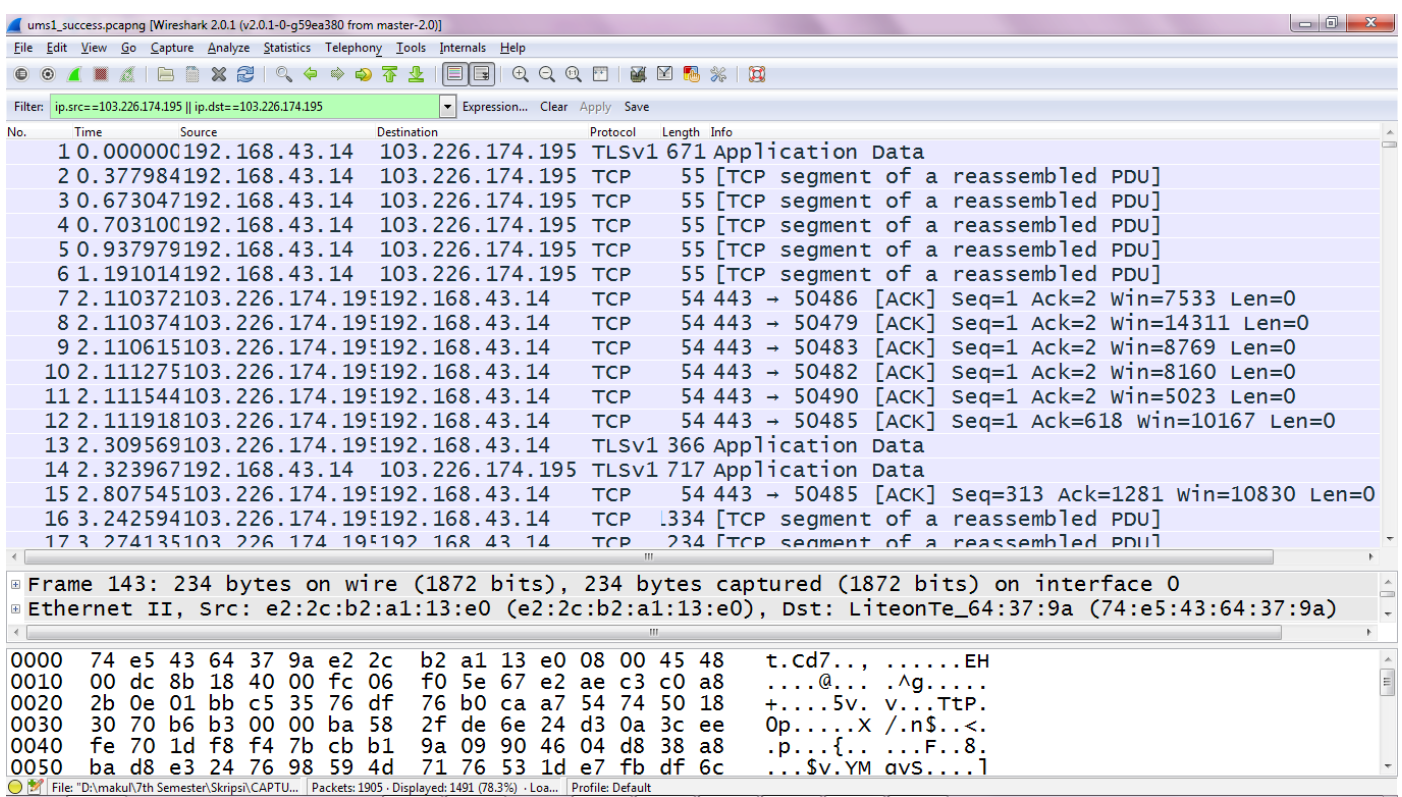

Gambar 13. Hasil Analisa Wireshark pada Sistem KRS Online

Dari hasil analisa dengan menggunakan Wireshark, didapatkan jumlah data yang ditransfer selama mengakses sistem tersebut adalah sebesar 670581 bytes atau 654,86 kilobytes. Jumlah tersebut terbagi dalam dua jenis data, yaitu data incoming adalah sebesar 531515 bytes atau 519,06 kilobytes dan data outgoing sebesar 139066 bytes atau 135,81 kilobytes. Selain itu, didapatkan data mengenai total waktu yang dibutuhkan selama mengakses sistem yaitu sebesar 178,70 detik dengan asumsi waktu direkam berdasarkan aktivitas-aktivitas yang dilakukan dari awal hingga akhir beserta posisi diam (idle) pada saat pengaksesan sistem.

\section{2) Pengujian pada Aplikasi SPA}

Pengujian terhadap aplikasi SPA dilakukan dengan cara yang sama dengan pengujian pada sistem KRS online. Hal pertama yang dilakukan adalah menentukan IP dari server tempat aplikasi dijalankan. Server yang digunakan untuk men-deploy aplikasi SPA mempunyai alamat IP 185.28.20.88. Alamat IP tersebut kemudian digunakan sebagai filter IP pada Wireshark dengan menggunakan perintah filter ip.src $==185.28 .20 .88$ || ip.dst $==185.28 .20 .88$. Langkah kedua pengujian adalah menginisiasi proses capturing pada Wireshark. Langkah ketiga adalah mengakses aplikasi SPA dengan melakukan tahapan aktivitas seperti pada Gambar 14. Setelah seluruh tahapan aktivitas dijalankan, langkah berikutnya adalah mengakhiri proses capturing Wireshark lalu menyimpan hasilnya ke sebuah berkas berekstensi pcap

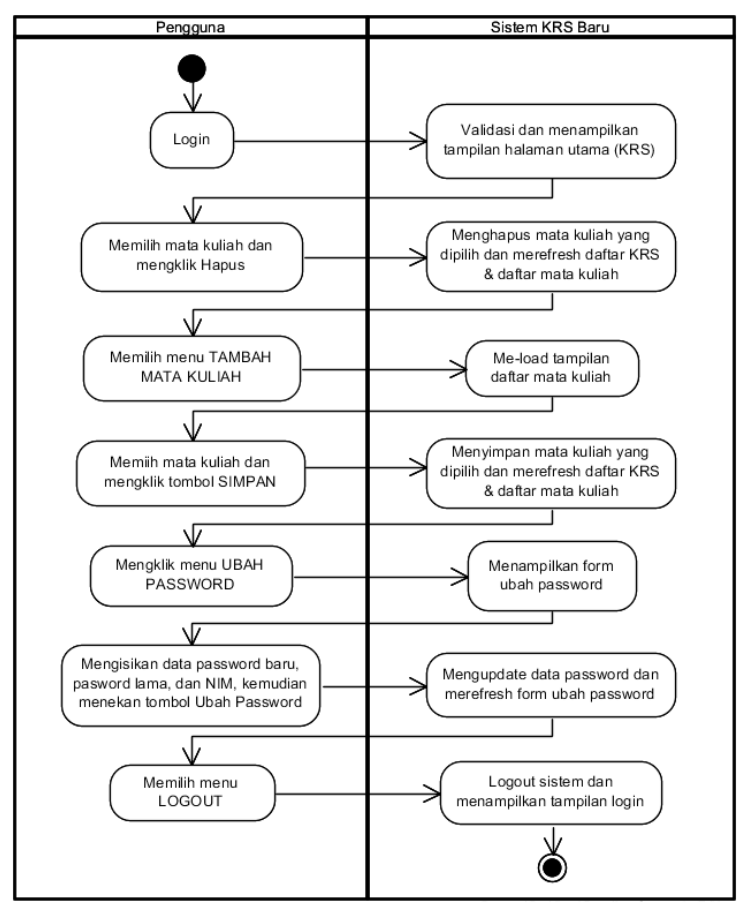

Gambar 14. Aktivitas Selama Mengakses aplikasi SPA 


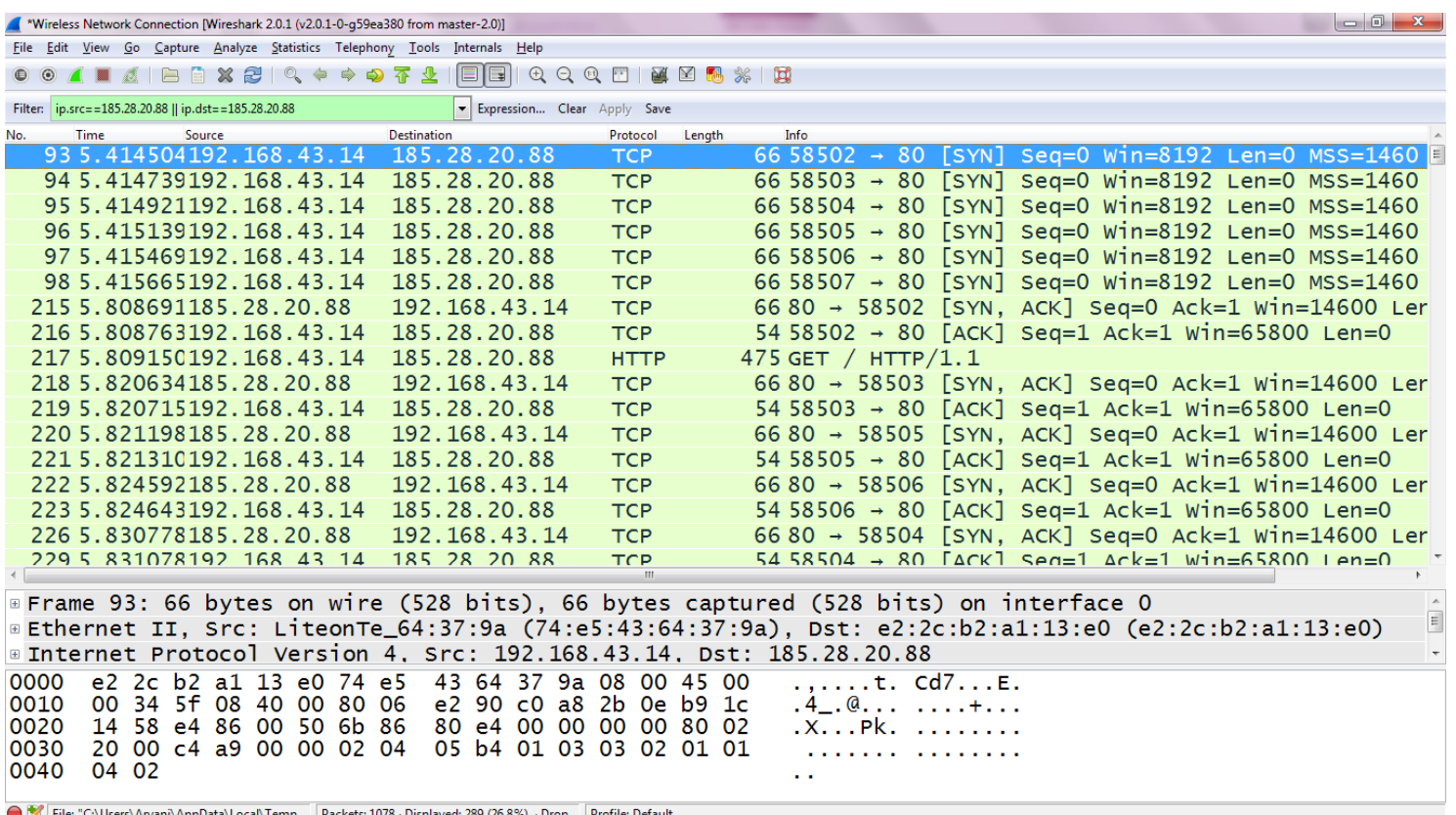

Gambar 15. Hasil Analisa Wireshark pada aplikasi SPA

Aktivitas-aktivitas tersebutlah yang dianalisis menggunakan Wireshark. Hasil analisa menggunakan Wireshark meliputi informasi mengenai paket data yang ditransfer selama mengakses sistem seperti yang terlihat pada Gambar 15. Dari hasil analisa menggunakan Wireshark, didapatkan jumlah data yang ditransfer selama mengakses aplikasi SPA adalah 54182 bytes atau 52,91 kilobytes. Jumlah tersebut terbagi dalam dua jenis data, yaitu data incoming sebesar 27000 bytes atau 26,37 kilobytes dan data outgoing sebesar 27182 bytes atau 26,54 kilobytes. Selain itu didapatkan total waktu yang diperlukan selama pengaksesan sistem yaitu sebesar 64,71 detik dengan asumsi waktu direkam berdasarkan aktivitas-aktivitas yang dilakukan dari awal hingga akhir beserta posisi diam (idle) pada saat pengaksesan sistem.

Data pengujian sistem KRS online dan aplikasi SPA kemudian dihimpun ke dalam satu tabel untuk mempermudah perbandingan kinerja keduanya (Tabel 1). Pada tabel tersebut, total data transfer merupakan hasil penjumlahan antara data incoming dan outgoing. Sedangkan waktu transfer menunjukkan waktu yang dibutuhkan dalam melakukan keseluruhan aktivitas di mana waktu idle diasumsikan minimum karena pengujian dilakukan secepat mungkin.

Tabel 1. Kinerja Sistem KRS online UMS dan aplikasi SPA

\begin{tabular}{lccc}
\hline $\begin{array}{c}\text { Data kinerja untuk menyelesaikan } \\
\text { seluruh tahapan aktivitas }\end{array}$ & Sistem KRS Online & Aplikasi SPA & $\begin{array}{c}\text { Perbandingan kinerja } \\
\text { (Sistem KRS Online: Aplikasi SPA) }\end{array}$ \\
\hline Data Incoming (kilobyte) & 519,06 & 26,37 & $20: 1$ \\
Data Outgoing (kilobyte) & 135,81 & 26,54 & $5: 1$ \\
Total data transfer (kilobyte) & 654,86 & 52,91 & $12: 1$ \\
Waktu transfer (detik) & 178,70 & 64,71 & $3: 1$ \\
Rata-rata kecepatan transfer (kbps) & 29,32 & 6,54 & \\
\hline
\end{tabular}

\subsection{Diskusi}

Tabel 1 menampilkan hasil pengujian aplikasi SPA, yang dibuat untuk penelitian ini, dibandingkan dengan pengujian sistem KRS online, yang sedang digunakan di Universitas Muhammadiyah Surakarta. Data pengujian diperoleh menggunakan perangkat lunak Wireshark. Pengujian kinerja menggunakan Wireshark terutama dilakukan jika dibutuhkan detil data yang ditransfer antara server dan client (yaitu browser internet) beserta waktu kejadiannya, misalnya pengujian kualitas video streaming pada [6] dan pengujian kinerja server email pada [7]. Pada penelitian ini, Wireshark digunakan untuk mendapatkan jumlah data yang ditransfer saat dilakukan proses KRS, yaitu perekaman data rencana studi mahasiswa, baik pada aplikasi SPA maupun pada sistem KRS online.
Tabel data kinerja (Tabel 1) menunjukkan bahwa aplikasi SPA memerlukan transfer data sebesar 52,91 KB, yang lebih kecil dibanding transfer data pada sistem KRS online sebesar $654,86 \mathrm{~KB}$. Terjadi perbaikan signifikan terkait jumlah data yang ditransfer untuk melakukan aktivitas yang setara. Perbaikan tersebut mungkin terjadi karena beberapa alasan. Pertama, jumlah tahapan kegiatan pada sistem KRS online lebih banyak dibanding pada aplikasi SPA untuk melakukan pekerjaan yang sama. Gambar 12 menunjukkan bahwa sistem KRS online membutuhkan sembilan langkah untuk melakukan satu proses login, menghapus satu mata kuliah dari daftar KRS, menambah satu mata kuliah yang lain, mengubah password dan melakukan logout. Sembilan langkah tersebut harus dilakukan oleh pengguna dan ditanggapi 
oleh sistem. Sedangkan aplikasi SPA hanya membutuhkan tujuh langkah untuk melakukan hal yang sama (lihat Gambar 14). Pada sistem KRS online, setiap langkah membutuhkan respon berupa pemuatan (loading) halaman web sehingga jumlah langkah yang lebih banyak berarti jumlah data yang harus ditransfer dari server ke browser (yaitu data incoming) menjadi lebih banyak.

Data yang ditransfer ke server dari browser (atau data outgoing) pada sistem KRS online juga lebih besar sampai lima kali lipat lebih banyak dibanding data outgoing pada aplikasi SPA. Namun perbedaannya tidak seekstrem pada data incoming, yang mencapai 20 kali lipat. Hal ini karena data outgoing yang berasal dari browser tidak banyak berbeda antara sistem KRS online dan aplikasi SPA, yaitu berupa data perubahan daftar rencana studi (KRS) dan data permintaan perubahan password. Selebihnya perbedaan muncul karena jumlah byte overhead yang dikirim oleh browser karena jumlah permintaan (request) yang berbeda terkait jumlah langkah aktivitas yang berbeda.

Selanjutnya waktu yang dibutuhkan untuk melakukan 9 langkah aktivitas pada sistem KRS online sebesar sekitar 3 menit sedangkan pada aplikasi SPA dibutuhkan hanya 1 menit. Sebenarnya perbedaan waktu tersebut tidak dapat diperbandingkan secara fair karena kedua aplikasi berada pada server yang berbeda di lokasi yang berbeda. Kecepatan transfer data saat akses sistem KRS online bisa mencapai 29,32 kbps sedangkan kecepatan akses ke server aplikasi SPA hanya 6,54 kbps. Walaupun begitu, karena data yang ditransfer pada akses sistem KRS online lebih banyak, maka waktu yang dibutuhkan menjadi lebih lama. Meskipun sistem KRS online didukung oleh perangkat dan bandwidth yang lebih baik, namun ternyata kinerjanya tidak lebih baik.

Uraian paragraf terdahulu memberikan indikasi bahwa jika infrastruktur yang melayani aplikasi SPA setara dengan infrastruktur yang melayani sistem KRS online, akan diperoleh penghematan bandwidth dan waktu baik dari sisi server maupun dari sisi pengguna. Indikasi itu sesuai dengan pernyataan yang dikemukakan Jadhav, dkk. [3] bahwa penerapan Single Page Application (SPA) dapat menghemat bandwidth serta waktu karena seluruh resources dibebankan pada pengaksesan sistem di awal dan berubah sesuai respon server atas interaksi klien tanpa menyegarkan seluruh halaman.

Penggunaan bandwidth yang kecil dan respon waktu yang singkat akan memberikan kenyamanan kepada pengguna aplikasi. Hal ini dapat memberikan pengalaman pengguna yang tinggi dan tidak akan mengecewakan ketika menggunakan SPA [8]. Selain itu penggunaan AngularJS untuk penerapan SPA membuat kode program mudah untuk dibaca dan dimengerti yang merupakan bagian paling penting dalam hal responsivitas antar muka pengguna [3].

\section{Penutup}

\subsection{Kesimpulan}

Penelitian ini menghasilkan aplikasi yang tergolong Single Page Application, yaitu aplikasi yang menempatkan sebuah tugas yang terdiri atas beberapa tahap dalam satu halaman web dengan satu URL. Aplikasi yang dibuat terdiri atas lima tampilan yaitu tampilan login, tampilan utama, tampilan daftar rencana studi (KRS), tampilan tambah mata kuliah dan tampilan ubah password. Kinerja aplikasi SPA dibandingkan dengan kinerja sistem KRS online yang masih digunakan. Pengukuran data kinerja dilakukan menggunakan Wireshark. Hasil penelitian menunjukkan bahwa aplikasi SPA memerlukan transfer data yang jauh lebih sedikit dibanding sistem KRS online untuk melakukan pekerjaan yang setara. Tahapan yang harus ditempuh lebih sedikit dan waktu yang dibutuhkan untuk menyelesaikan pekerjaan yang sama juga lebih sedikit. Artinya, penerapan single page application pada proses KRS terbukti dapat memperbaiki kinerja sistem dengan mengurangi bandwidth yang dibutuhkan dan mengurangi waktu total proses KRS.

\subsection{Saran}

Penelitian ini berfokus pada jumlah data yang ditransfer dan waktu untuk melakukan proses KRS. Sebelum konsep ini diterapkan, ada baiknya dilakukan penelitian tentang keamanan aplikasi karena SPA menggunakan Javascript yang kodenya dapat dilihat/dibaca oleh pengguna yang mempunyai pengetahuan tentang pemrograman.

\section{Daftar Pustaka}

[1] Tim Penyusun, Buku Panduan Akademik, Surakarta: Fakultas Komunikasi \& Informatika, 2012.

[2] _ Sistem Informasi Akademik, 2014. Diakses dari https://akademik.ums.ac.id/ tanggal 25 Maret 2016.

[3] M. A. Jadhav, B.R. Sawant \& A. Deshmukh, "Single Page Application using AngularJS," dalam International Journal of Computer Science and Information Technologies, 6 (3), hal. 2876, 2015.

[4] M.S. Mikowski \& J.C. Powell, Single Page Web Application. Shelter Island: Manning Publications Company, 2014.

[5] U. Lamping, R. Sharpe \& E. Warnicke, Wireshark User's Guide: For Wireshark 2.1. Boston: The Free Software Foundation, 2014.

[6] D.T. Massandy, \& I.R. Munir, "Secured video streaming development on smartphones with android platform," In Telecommunication Systems, Services, and Applications (TSS A), 7th International Conference on, hal. 339-344, IEEE, 2012.

[7] H. Thamrin, "Beban Jaringan Saat Mengakses Email Dari Beberapa Mail Server," in Prosiding Seminar Nasional Sains Dan Teknologi Fakultas Teknik, 1(1), 2010.

[8] R.J. Joseph, "Single Page Application and Canvas Drawing," International Journal of Web \& Semantic, 6 (1): $29-30,2015$. 